\title{
Research on the application of Chinese traditional culture in the staff training of logistics enterprises
}

\author{
Cai Su, Xueqiang Li, Jing Li, Qingjun Fang \\ Qingdao Huanghai University, Qingdao Shandong 266427
}

Keywords: Chinese traditional culture, Staff training, Logistics enterprises

\begin{abstract}
. 5000 years of history in our country, in the five thousand years of history, the formation of the excellent traditional culture has China characteristics. Keep the cultural needs of the process we are constantly on the Qucuqujing era, and requires a combination of its continuous development. In order to apply it to modern logistics enterprise management to promote the logistics enterprise, staff training, and promote the development of modern logistics enterprise management. We carry out an analysis on the value of traditional culture in the modern enterprise management, puts forward the traditional culture methods in the application of the modern enterprise.
\end{abstract}

\section{Modern enterprise management and traditional culture}

China traditional culture contains vigorous, harmony, harmony medium rich thoughts, is the embodiment of the national spirit of the Chinese nation, has a strong vitality and cohesion. The traditional enterprise and enterprise culture composed of enterprise culture, including the formation of internal values. The function of enterprise culture is in many aspects, mainly includes the following aspects.

First, the cohesion functions. Because the corporate culture will play a role in the assimilation of intangible, standardization and integration, comprehensive effect in these three kinds of function, enterprise culture can enhance the cohesion of the enterprise; this is the enterprise cohesion function. The enterprise can unite the cohesion function and value of two aspects through condensation the so-called target. By setting enterprise cohesion is more prominent, clear and focused goal to regulate and influence the staff and the public perception of group behavior, and guide enterprises of all employees toward the same direction fight, the formation of enterprise internal cohesion. The value of cohesion refers to the employees of common values driven by the formation of common goals and interests, so that employees the same goal, unity and cooperation.

Second, has the incentive function. The incentive function mainly refers to the enterprise culture in the morale of the function of enterprise culture under the premise of people-oriented, create a cultural atmosphere of equality, to inspire employees strive for progress and development of enterprises. The incentive function of the enterprise culture of employees from an invisible the spirit and the spirit of binding force. The enterprise culture can help employees understand the meaning of their business to the society, to start their own understanding as employees for the enterprises, resulting in the consciousness of the sense of mission and master, so as to realize their value for the enterprise to work consciously to work harder. Third, has the guiding function. Enterprise culture is a kind of powerful culture, can reflect the enterprise staff's common values and pursuit. The formation of enterprise culture will establish a standard value and standard of matching, consistent so as to guide the enterprise staff's thought and value orientation and the whole enterprise. With the guidance function enterprise culture can create a good corporate culture, so as to guide enterprises to members of the specific behavior and psychology, values of penetration in the subtle enterprise in work and life, encourage employees to voluntarily for the realization of goals struggle. Fourth, has the promotion function. Enterprise culture promoting function is established on the basis of economic independence with respect to culture the interaction between culture and economy in certain conditions can become an economic development oriented culture. Corporate culture to promote the function embodied in 
Enterprises the overall state of the economy, education, science, and so on, is the result of many aspects.

\section{The relationship between traditional culture and enterprise culture and enterprise management}

The traditional culture of China Chinese existing values and ways of thinking had a profound impact, impact on the enterprise through the individual in the enterprise activities. Enterprises, entrepreneurs and employees to the performance in the development of specific practice of traditional culture through their own behavior. The enterprise culture is the traditional culture in the enterprise, the two the relationship between the main aspects is as follows. Firstly, influence the formation of enterprise values. The influence of traditional culture on enterprise values is the most profound, the social environment in which the individual directly affects the formation of personal values.

The enterprise values as individual values of sublimation, is the enterprise staff identity of interests of enterprises and the society. The two common also have contradiction, contradiction of reasonable adjustment, is conducive to mobilize the enthusiasm of the staff work, to promote the development of enterprises. Secondly, the enterprise values are mostly derived from good in the traditional culture, is the direct source of enterprise culture, embodies the enterprise culture, on the other hand, the values for the enterprise development direction.

In the modern logistics enterprise management and staff training can be found in the traditional culture idea of shadow, you can see some of the ideas and methods of management of modern enterprises can find the source in the traditional culture. As Confucianism is the summary and lessons learned in the process of social practice, combined with the actual situation of modern, deepening and sublimation the theory of enterprise management. In effect, with the spirit of traditional culture ideological development of business strategy management of the enterprise it. One of the more influential is the art of war, Chinese military thought by the attention of entrepreneurs, strategic focus on operational valance, emphasis on "strategy", "seek to attack all respected" and "changing for success", which in today's society is flexible and changeable.

Of course, the traditional culture is produced in the China traditional background and development, meet the needs of social development, under the new social background, we want to in the modern enterprise management of traditional culture to use, must be in accordance with the background of social development at present and the enterprise's own status transformation, the only in this way, it can have a positive role in promoting the development of modern enterprise management. At the same time, the essence of China exists not only in traditional culture, there are dross, we want in the modern logistics enterprise management to take advantage of it, and should be good, you need to keep your eyes open, constantly Quweicunzhen Qucuqujing, finally realize the good the desire to promote the development of modern logistics management enterprise with excellent traditional culture. 
Table 1. A survey of Chinese traditional culture in enterprise employees

\begin{tabular}{|c|c|c|}
\hline \multicolumn{2}{|r|}{ Survey question } & \multirow{2}{*}{$\frac{\text { Proportion }}{5 \%}$} \\
\hline \multirow{3}{*}{$\begin{array}{l}\text { Understanding } \\
\text { of traditional } \\
\text { culture }\end{array}$} & less & \\
\hline & many & $55 \%$ \\
\hline & Very understanding & $40 \%$ \\
\hline \multirow{3}{*}{$\begin{array}{c}\text { The relationship } \\
\text { between } \\
\text { traditional } \\
\text { culture and } \\
\text { enterprise } \\
\text { development }\end{array}$} & no relevance & $5 \%$ \\
\hline & Little relationship & $20 \%$ \\
\hline & Mutual influence & $75 \%$ \\
\hline \multirow{3}{*}{$\begin{array}{c}\text { The relationship } \\
\text { between } \\
\text { traditional } \\
\text { culture and } \\
\text { logistics } \\
\text { enterprises } \\
\end{array}$} & $\begin{array}{l}\text { Influence the direction of enterprise } \\
\text { development }\end{array}$ & $20.5 \%$ \\
\hline & Influence employee training mode & $25 \%$ \\
\hline & $\begin{array}{l}\text { Influence the direction of enterprise } \\
\text { development and employee training mode }\end{array}$ & $95 \%$ \\
\hline \multirow{4}{*}{$\begin{array}{c}\text { appraisal; } \\
\text { self-assessment ; }\end{array}$} & $\begin{array}{c}\text { Traditional culture on the development of } \\
\text { Education }\end{array}$ & $36 \%$ \\
\hline & $\begin{array}{l}\text { Learning the traditional culture to improve } \\
\text { their work quality and work skills }\end{array}$ & $42 \%$ \\
\hline & Able to learn and work freely & $35.3 \%$ \\
\hline & $\begin{array}{l}\text { Through training and cultural learning to } \\
\text { make their work happy }\end{array}$ & $75.7 \%$ \\
\hline
\end{tabular}

\section{The application of traditional culture in modern enterprise management}

In the spring and Autumn period, the legalist school proposed the ideas of the rule by law, construct perfect laws to govern the country, realize the rule of purpose. And put forward the thought of Confucian benevolence; advocate a benevolent to obtain political authority, so as to realize people's true obedience. The two ruling monarch views in different ruling period have different emphases, but by the dark, the continuous development of promoting China's feudal system. In the management and training process of logistics enterprises, combined with the rule of law and the benevolence has its own special meaning of the rule of law in the logistics enterprises. Management is to establish and perfect enterprise management system, through the system to realize the management of employees and reward, encourage employees to comply with the system under the premise to the quality and quantity to complete the task. The implementation of Ninji in logistics enterprise management, management is in the process of continuous understanding of the special circumstances of their own employees, and effectively solve the various problems in their work and lives, so that employees have a sense of belonging to the enterprise, which spontaneously service for the enterprise. In the enterprise management and constantly promote the combination of law and benevolence can continuously improve the management efficiency, improve staff management effect.

Chinese traditional culture seems to sum of historical experience related, but has nothing to do with science. In fact, many China traditional ideas contain certain science, traditional thought of the science if it is in the modern logistics enterprise management and rational utilization, can promote the continuous development of modern logistics enterprise management, harmonious thought is one the sign. The harmonious thought is Buddhism and Confucianism have advocated the thought, its main view is the harmony of person and person, person and society's harmony and the harmony between man and nature that is to realize "in the process of development of the harmony between man and nature". The harmony of person and person is the interpersonal relationship, do not take the initiative to stir up trouble no, on the back of people, everyone mutual help; the harmony of man and society refers to the personal development should be consistent with the trend of social development, not to be able to reverse the tide; the harmony between man and nature refers to the human development should respect the law of development of nature, not to destroy the balance of nature. The application 
of the idea of harmony in modern logistics enterprise management is mainly reflected in the guiding ideology of management. First of all, realize the harmony of people and people in the management. The modern enterprise management should be to promote harmony among employees for the purpose, only a good relationship between employees, between employees can continue to help each employee personal emotion to raise, the enterprise can fast development continuously. On the contrary, if employees envy each other, mutual constraints, it is easy to affect the employee's working state, affect the company's efficiency, and continue to hinder the development of the company. Second, continue to promote enterprise and social harmony in the management. The harmonious development of human and nature in the traditional culture in the modern enterprise management can be extended to harmony the development of the enterprise and society. That is the development of enterprises should conform to the trend of social development, continue to undertake the social responsibility, should not be separated from the background of the times and space development. Finally, the relationship between man and nature in modern logistics enterprise management should be extended to the relationship between enterprise development and the law of nature. The logistics enterprise management should not only follow the law of social development, should also follow the natural development of the law, the laws of nature are constantly using good training to promote development in logistics enterprises and employees.

China's traditional culture has many proverbs are described in words, such as a rainy day, and prevent trouble before it happens, that only always be vigilant, can teach us. This is prepared against want, in stable condition, can not let down, should polish eyes, the time to prepare, to avoid will be taken by surprise. In modern logistics enterprise management, should continue to implement the peace ideas. First, to carry out the idea of peace staff so that it can keep the awe and vigilance of Italy in the work, to avoid and prevent risks. At the same time, let the staff have the sense of competition, which is constantly aware that at any time excellent talents can replace its position, so that employees can continue to study, maintain their competitive advantage. Second, carry out the danger in the development of logistics enterprises in mind, is to allow enterprises to fine umbrella, filled with food, constantly on the rules of social development were predicted and analyzed, so as to make the right judgments, so that enterprises continue to win in the fierce competition in society.

The training of management personnel is one of the key of modern enterprise management, so to build a diversified training service mechanism, strengthen the training efforts, the specific circumstances of the enterprise to talented person's demand structure and other aspects of the understanding and analysis of talent, psychological needs and internal potential, the first of its holistic values of the enterprise, to create a good training environment

Secondly, always adhere to the talent education training in moral education and, by providing individual career planning training, part-time training, study abroad training of diversified talents training mode, and realize the sustainable development of enterprise personnel, to provide strong human resources support to improve the comprehensive competitiveness of enterprises.

In summary, there is a very big role in promoting culture development and staff of traditional culture to modern logistics enterprise management, it can promote the modern logistics enterprise management constantly meet the habits of cognitive and behavioral Chinese. So we need to affirm the role of traditional culture in the modern logistics enterprise management constantly, constantly updating based on the traditional culture, promote the traditional culture and the modern logistics enterprise management combined. At the same time, we need to deepen the understanding of traditional culture, in modern logistics enterprise management constantly realistically with traditional culture, in order to achieve the ultimate goal of improving the efficiency of enterprise management. 


\section{Acknowledgements}

Supported by Shandong Youth Quality Education Subject: Project Number:ZY201610066 Supported by Shandong Province Cultural Department Subject

\section{References}

[1]Nanyan Huo.Thinking and practice of strengthening the education and training of the new generation of employees by using traditional culture.(J), 2016,48 (S1).

[2]Hailiang Zhang. The application of traditional culture in Enterprises.2014 (17).

[3]Xiyue Lu. The application of _ Chinese traditional culture in enterprise management on core value of corporate culture. 2014 (12).

[4]Junhua $\mathrm{Xu}$. The application of traditional culture in modern enterprise management. 2015 (3).

[5]Yanni Qu. The influence of Chinese traditional culture on the construction of modern enterprise culture. 2015 (6). 